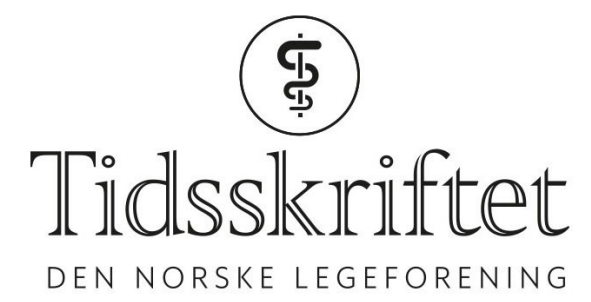

\title{
Falskt forhøyet troponinverdi
}

DEBATT

\section{ELLEN BØHMER}

E-post:ebhmer@gmail.com

Ellen Bøhmer (f. 196o) er spesialist i indremedisin og $\mathrm{i}$ kardiologi. Hun er seksjonsoverlege ved Medisinsk avdeling, Sykehuset Innlandet, Lillehammer.

Forfatter har fylt ut ICMJE-skjemaet og oppgir ingen interessekonflikter.

Ved utredning av brystsmerter har kardiale troponiner en helt sentral plass. I klinisk arbeid er man godt kjent med at andre tilstander enn hjerteinfarkt kan gi forhøyet troponinnivå, men muligheten for falskt forhøyet prøve synes å være lite kjent.

Jeg presenterer her en kasuistikk som illustrerer problemet med falskt forhøyet troponinverdi, og konsekvensene av å overse denne tolkningsmuligheten.

For å diagnostisere hjerteinfarkt er det krav om stigning og/eller et fall i troponinverdi med minst én verdi > 99-prosentilen i en frisk referansebefolkning, sammen med iskemiske tegn eller symptomer (1). Troponin T og troponin I oppfattes som likeverdige i diagnostikken av hjerteinfarkt. Det finnes bare én produsent av tester for troponin T og således bare ett referanseområde. For troponin I foreligger en rekke produsenter av tester med ulike referanseområder.

Det har vært diskutert hvor stor endring som skal til for å kunne stille diagnosen hjerteinfarkt. Det er blitt konkludert med krav om 50 \% endring for verdier rundt 99prosentilen og $20 \%$ ved høyere nivåer av troponiner (2).

Utviklingen har gitt mer sensitive troponintester. Det er dermed mulig å fange opp stigning tidligere i forløpet av et hjerteinfarkt, men dette går på bekostning av spesifisiteten. Økt troponinverdi taler vanligvis for myokardskade, men sier ikke noe om mekanismen for skaden. Det foreligger en rekke sykdommer som kan gi myokardskade. Ved alvorlig nyresvikt kan redusert eliminasjon gi forhøyet verdi. Dagens troponintester har svært høy sensitivitet og kan være sant forhøyet uten at det må være patologiske funn ved andre laboratorietester, koronar angiografi eller radiologiske undersøkelser. Når vi her snakker om falskt forhøyet troponinverdi, er det fordi en alternativ test for troponin har gitt en normal verdi.

\section{En kasuistikk}

En mann i slutten av 6o-årene med kostregulert diabetes mellitus, moderat kronisk obstruktiv lungesykdom (kols), normal nyrefunksjon og lett hypotyreose (negativ thyroideareseptorantistoff (TRAS) og negativ anti-TPO) hadde hatt flere innleggelser på grunn av dyspné og koronarsuspekte brystsmerter. 
I løpet av de siste 15 årene var han undersøkt fem ganger med koronar angiografi med funn av normale kar. Fire av disse undersøkelsene ble utført i løpet av fire år, og i denne perioden forelå 25 verdier for troponin $\mathrm{T}$ i intervallet 50-120 ng/l. Det ble tatt en rekke proBNP-verdier og ultralydundersøkelser av hjertet. MR-undersøkelse av hjertet viste ikke tegn til myokarditt. Da man differensierte mellom ulike troponiner, fant man at troponin T var forhøyet på $100 \mathrm{ng} / \mathrm{l}$ (øvre referansegrense $14 \mathrm{ng} / \mathrm{l}$ ), mens troponin I var innenfor referanseområdet på $26 \mathrm{ng} / \mathrm{l}$ (øvre referansegrense $34 \mathrm{ng} / \mathrm{l}$ ).

Påvisning av normalt nivå for troponin I reduserte bekymringen til pasienten, og det ble vesentlig lettere å forklare smertene som muskulære. Senere har det ikke vært innleggelser med denne problemstillingen. Vi fant ingen forklaring på den falskt forhøyede verdien av troponin $\mathrm{T}$.

\section{Klinisk erfaring}

Analyse av troponin rekvireres selv ved svært lav mistanke om hjerteinfarkt eller annen myokardskade. Det øker sannsynligheten for å finne en falskt forhøyet prøve.

Vi har mistenkt falskt forhøyet verdi ved atypiske eller åpenbart ikke-koronare brystsmerter, fravær av andre sykdommer som kan forklare en forhøyet verdi, normalt EKG, fravær av patologi ved koronar angiografi og eventuelt MR-undersøkelse av hjertet. Liten endring av verdi fra første til andre prøve kan gi en første mistanke om at det ikke dreier seg om et akutt infarkt, men flere pasienter med falskt forhøyet troponinnivå tilfredsstilte kravet om $20 \%$ endring. Ved reinnleggelser har forhøyede troponiner i samme nivå som ved tidligere opphold, kunnet gi mistanke om falskt forhøyet troponinverdi.

Bekreftelsen av mistanken om falskt positiv test av troponin $\mathrm{T}$ har vært å sende lagret serum fra samme prøve til analyse ved et annet sykehus som har benyttet troponin I (ES Vitros). Til tross for klart forhøyet troponin T-nivå, har analyse av troponin I fra samme prøve vært innenfor referanseområdet.

I litteraturen anbefales bred utredning med tanke på hjertesykdom, hvilket oftest innebærer både koronar angiografi og MR-undersøkelse av hjertet (3). Disse undersøkelsene gjøres bare på større sykehus, og overflytting av pasienter for dette utløser mye ressurser.

Kasuistikken illustrerer at enkelte pasienter blir utsatt for omfattende utredning på grunn av forhøyede troponinverdier. Min erfaring er at enkelte av disse pasientene hadde symptomer som ikke tilsa en så omfattende utredning, men der de uavklarte forhøyede troponinverdiene drev frem både ekstra undersøkelser under oppholdet og kontroller etter utskrivning. Pasienter innlagt med brystsmerter har vanligvis kort liggetid på sykehus. Det er således ønskelig med tilgang til en alternativ troponintest som gir svar samme dag, slik at man unngår omfattende utredning som det ikke er grunnlag for ut fra klinisk bilde og EKG.

\section{Årsaker og håndtering}

Hvis man ser bort fra forbytting av prøveglass, angis følgende årsaker til falskt forhøyet troponinverdi $(3,4)$ : Heterofile antistoffer, humane antidyreantistoffer, autoantistoffer, fibrin, revmatoid faktor, endogene blodprodukter som bilirubin, hemoglobin og lipidemi, høy konsentrasjon av alkalisk fosfatase, immunkomplekser og feil ved analysemaskinen. Det angis at forekomsten av heterofile antistoffer er relativt vanlig slik at dette er den hyppigste forklaringen på en falskt positiv test (3).

Jeg har ikke funnet studier hvor man sammenligner testene for troponin T og troponin I med hensyn til sårbarhet for falskt forhøyet prøvesvar. Det er laget algoritmer både for laboratoriepersonell og klinikere ved mistanke om falskt positiv test (4).

Første tiltak er en ny prøve for å se om det er uendret resultat eller eventuelt hemolyse. Deretter anbefales å utelukke annen hjertesykdom enn akutt koronar syndrom før man tar kontakt med laboratoriet for hjelp til avklaring og eventuelt testing $\mathrm{i}$ et annet immunoassay. Det angis at både troponin I og T kan gi falskt positive verdier, men at 
prevalensen er svært usikker $(3,4)$.

Det er viktig å være klar over muligheten for en falskt forhøyet troponinverdi. Dette bør overveies når klinisk bilde og troponinsvar ikke passer sammen. Min erfaring er at tidlig kontakt med laboratoriet og kontroll med annen metode kan spare pasienter for unødvendige diagnostiske prosedyrer og bekymring.

\section{LITTERATUR:}

1. Thygesen K, Alpert JS, Jaffe AS et al. Third universal definition of myocardial infarction. Eur Heart J 2012; 33: 2551 - 67. [PubMed][CrossRef]

2. Aakre KM, Rotevatn S, Hagve T-A et al. Nasjonale anbefalinger for tolkning av troponinverdier ved diagnostikk av akutt hjerteinfarkt. Tidsskr Nor Legeforen 2013; 133: 2241 - 2. [CrossRef]

3. Vafaie M, Biener M, Mueller M et al. Analytically false or true positive elevations of high sensitivity cardiac troponin: a systematic approach. Heart 2014; 100: 508 - 14. [PubMed][CrossRef]

4. Lum G, Solarz DE, Farney L. False positive cardiac troponin results in patients without myocardial infarction. Labmedicine 2006; 37:546 - 50.

Publisert: 18. august 2017. Tidsskr Nor Legeforen. DOI:10.4045/tidsskr.17.0413

Mottatt 5.5.2017, første revisjon innsendt 15.5.2017, godkjent 2.6.2017.

(C) Tidsskrift for Den norske legeforening 2020. Lastet ned fra tidsskriftet.no 